\title{
Depositional and Structural Styles in the Logone Birni Basin (LBB), Northern Cameroon, from 3D Potential Field Modeling: Preliminary Results
}

\author{
Elad Mkoumbe1, Fosso Téguia M. Estelle Eric ${ }^{1,2}$, Eyike Yomba Albert ${ }^{*}$, \\ Njandjock Nouck Philippe ${ }^{3}$, Tabod Charles Tabod ${ }^{3}$ \\ ${ }^{1}$ Department of Physics, Faculty of Science, University of Douala, Douala, Cameroon \\ ${ }^{2}$ Branch for Geophysical and Volcanological Research/Institute of Geological and Mining Research, Buea, Cameroon \\ ${ }^{3}$ Department of Physics, Faculty of Science, University of Yaoundé I, Yaoundé, Cameroon \\ Email: *aeyike@gmail.com
}

How to cite this paper: Mkoumbe, E., Eric, F.T.M.E., Albert, E.Y., Philippe, N.N. and Tabod, T.C. (2019) Depositional and Structural Styles in the Logone Birni Basin (LBB), Northern Cameroon, from 3D Potential Field Modeling: Preliminary Results. Open Journal of Geology, 9, 226-244. https://doi.org/10.4236/ojg.2019.94016

Received: March 27, 2019

Accepted: April 25, 2019

Published: April 28, 2019

Copyright $\odot 2019$ by author(s) and Scientific Research Publishing Inc. This work is licensed under the Creative Commons Attribution International License (CC BY 4.0).

http://creativecommons.org/licenses/by/4.0/

(c) (i) Open Access

\begin{abstract}
A three-dimensional model of the Logone Birni Basin (LBB) is presented by combining gravity and magnetic data and constrained by broad seismic profiles. The 3-D model has revealed the distribution of the stratigraphic formations as well as the top basement variation. Detailed structure of different stratigraphic sequences is presented for the first time for this basin and some of the sequences correlate with established sequences of the neighboring basins. The sediments pill consists of six sedimentary units dating from the Neocomian to the Quartenary. The Makary subbasin or Northern Logone Birni Basin (NLBB) is the deepest part of the basin and may hold good prospect for hydrocarbon generation and accumulation. However, the limited presence of faults and intrusive bodies decreases the possibility of thermal degeneration, contrary to the Central Logone Birni Basin (CLBB) where conditions seem to be fulfilled for possible hydrocarbon generation and maturity. The complexity of the structural pattern of the model is further enhanced by the presences of volcanic bodies, some of which lay directly on basement or interbedded with the sediments layers mainly in the CLBB.
\end{abstract}

\section{Keywords}

Gravity/Magnetic Anomalies, Stratigraphic Sequences, Sediment Thickness, Logone Birini Basin, 3D-Model

\section{Introduction}

The Logone Birni basin (LBB) belongs to the Lake Chad basin, near the Doba 
basin where a huge oil field has been found. The LBB is subdivided into lower (or Southern Logone Birni Basin (SLBB)), middle (CLBB) and upper (NLBB) portions, and geographically located between latitudes $9^{\circ} 55^{\prime} \mathrm{N}$ to $13^{\circ} \mathrm{N}$ and between longitudes $14^{\circ} 10^{\prime} \mathrm{E}$ to $15^{\circ} 35^{\prime} \mathrm{E}$, in the transitional zone between the west and central African rift system (WCARS) (Figure 1(a)). It is tectonically limited by the Termit basin to the north, the Bongor and Doba basins to the south and southeast, and to the west by the Bornu basin. Although the generalities of the evolution of the Lake Chad basin have been widely recognized [1] [2] [3] [4] and show good prospect in petroleum exploration, most of the geological and geophysical data remain unpublished. Consequently, limited detailed work has been done to improve our understanding of the geological structure of the Logone

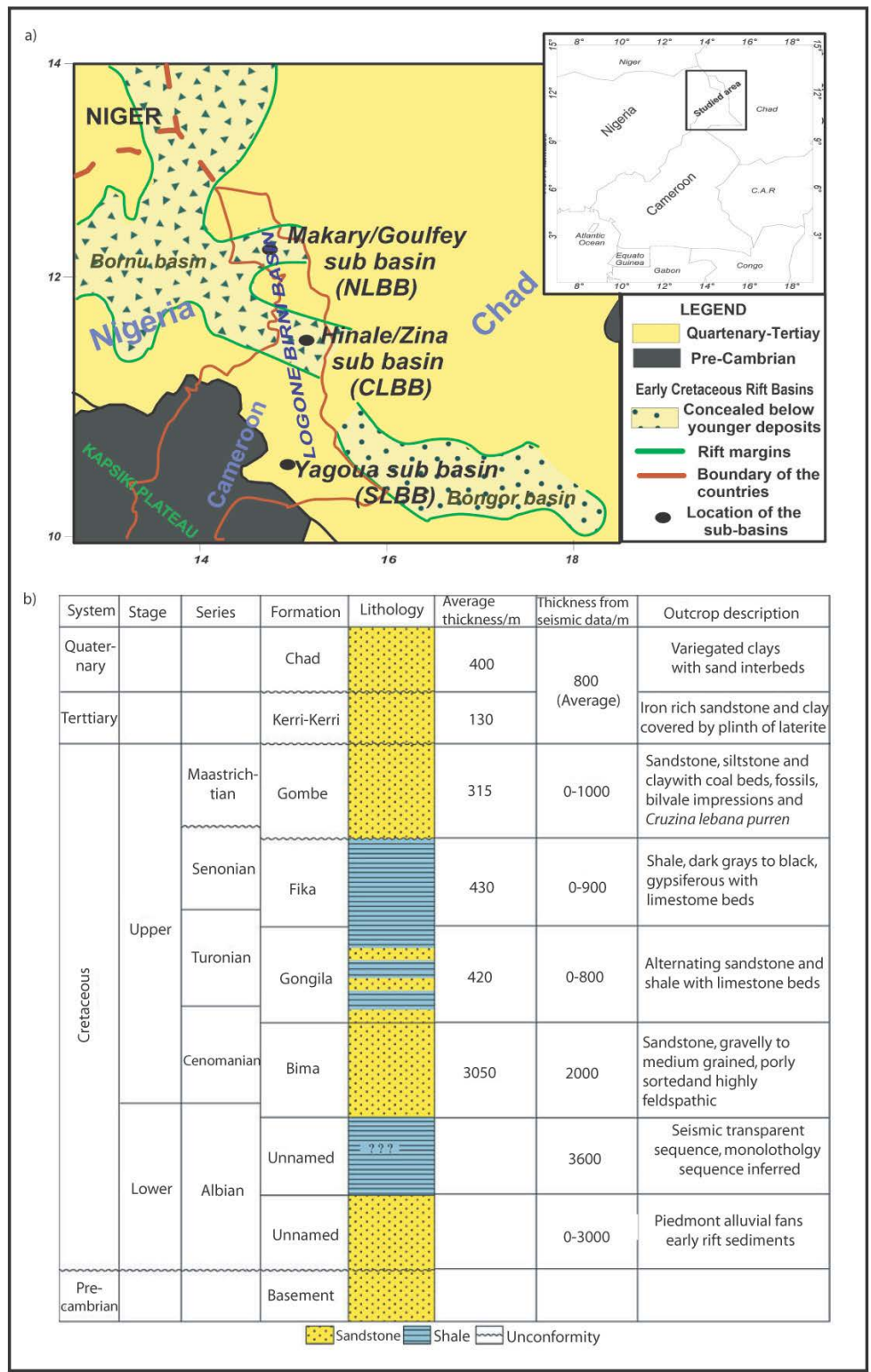

Figure 1. (a) Simplified geological map and location of the study area modified after Eyike and Ebbing [8]; (b) The Stratigraphy of the LBB [14]. 
Birni basin. However, potential field (gravity and magnetic) and seismic studies, or the combination of the two have provided broad information in the shallow and deep structure of this basin [5] by combining the spectral analysis and the 2.5D modelling of the gravity field proposed $3100 \mathrm{~m}$ as sediment thickness of the lower part of the basin, and the basement was intruded by volcanic rocks of Post-Cretaceous age. To further improve our knowledge on this basin, the major structural trends limiting different grabens and the distribution of the main buried volcanic bodies as well as their relationships with the structural and tectonic evolution were recently presented [6] [7]. It has been observed that the basin was associated with an intense volcanic activity during the Cretaceous, although the intrusive bodies were mainly confined to the basement. More recently, [8] [9] proposed the top basement map defining the sediment thickness distribution in the area, and they found that the basin contains up to $6000 \mathrm{~m}$ of Early Cretaceous to Recent sediments. Indeed, this model has improved our knowledge of the basement structure, but his accuracy is still limited due to lack of constrains, although it provides first order information in sediment thickness estimates. The other problem with these previous models is that they do not take into account different sediment sequences, whereas it is well known that knowledge of sediment stratigraphy is a key element to understand field scale lateral and vertical reservoir property and their fluid production [10]-[16]. Further, the possible occurrence of oil and gas in commercial quantities in the LBB has been a subject of controversy due to very scanty prospectivity data. Apart from above mentioned limited studies, no geochemical source rock data nor exploratory well has been drilled or identified in this basin. It is well known that petroleum is an exhaustible resource and dwindles on reserve with time. Therefore, it is imperative for a country like Cameroon, to continue the search for more oil and gas to add to its reserves. In the light of terrestrial gravity and aeromagnetic data, we propose a 3D geophysical model of different sediment strata in the LBB. The model is constrained by broad seismic sections. The main objective is to delineate areas with thick sedimentary formations and to localize possible hydrocarbons sources in the area. By shedding more light on the mineral and hydrocarbon perspectivity of the LBB, we also perhaps add to our reserves, for the betterment of our economy and development.

\section{Geology and Tectonic Background}

In this section, a brief review of the tectonic and surface geology is given. We refer the reader to [1] [14] [17] [18] [19] [20], for more extensive review of geology and tectonic setting of the study area and the West and African Rift System.

The study area is located in the transition zone between the Central and the West African rift systems (WCARS) as it is presented in Figure 1. [1] has shown that the origin of the WCARS sedimentary basins was characterized by three rifting phases after the Pan African crustal consolidation (750 - $550 \mathrm{Ma}$ ) and the Paleozoic-Jurassic development (550 - $130 \mathrm{Ma}$ ). The Neocomian to Aptian (130 
- 98) rifting phase was followed by thermal tectonic subsidence within the rifts (80 Ma - $75 \mathrm{Ma}$ ) whereby major marine transgression which reached northern Cameroon from the Tethys, to the north, through Mali and Algeria and from the South Atlantic, to the South, via the Benue Trough into western Chad and Niger [7]. The final episode (30 Ma - present) is the post rift uplift of high lands like the Cameroon Volcanic Line or the Adamawa regions facilitating the erosion and accumulation of more than important quantity of continental sediments in northern Cameroon and Lake Chad [1] [21].

\section{Stratigraphy}

To date, no exploratory wells have been drilled in northern Cameroon, the general stratigraphy is deduced from seismic data from the adjacent basins [1] [15] [20] [22].

A Generalized stratigraphic column of the LBB is shown in Figure 1(b). According to [7], sedimentation in the LBB was initiated during the Neocomian-Albian rifting period. From seismic and gravity modeling, more than 8000 $\mathrm{m}$ of sediments cover the crystalline basement in the deepest parts of the basin. The oldest sediments in the LBB attributable to the Pre-Bima are of Neocomian-Barremian age. They are made up of fluviolacustrine shale sands, characterized by possible piedmont alluvial fans Formation [7] [23]. This sequence is overlain by a Upper Albian sequence termed the Bima Santone Formation. On top of the Bima Formation is the Gongila Formation. This formation consists predominantly of sandstone and shale with limestone of Cenomaniam-Turonian in age. This Unit is overlain by the Turonian-Senonian Fika formation, which is made up of open marine shale deposited in shallow marine environment [4] [12] [24]. This Fika Formation is succeeded upward by the Senonian-Maastrichtian Gombe Formation, which is characterized by parallel to sub-parallel, discontinuous to chaotic reflectors, inter-bedded sand-shale [7]. The Quaternary Keri-Keri formation which overlies the Gombe formation is the uppermost layer in the LBB. It is essentially made up of sands to shale sands presenting low to high amplitude continuous and parallel reflectors [7].

\section{Method and Data}

We generally face major problems when construction geophysical models in Cameroon, due to lack of geological constrains (seismic reflection or refraction, density information and drillhole data...), which seriously limit the efficiency of previous models. However, using gravity and magnetic data, broad seismic lines and general information on sediment thickness in the area, we try to build a modelling strategy to obtain the geometry of different sediment strata in the LBB. We first calculate and remove effect of deep sources in gravity and magnetic using stripping residual and upward continuation methods for gravity and magnetic respectively. Then to image the geometry of different strata, we use these residuals fields to perform a 3D forward gravity and magnetic modeling 
constrained with density estimates, seismic profiles, together with geology and tectonic images. From this $3 \mathrm{D}$ model, we interpret three selected profiles crossing different subbasins in the LBB. The 3D forward modeling was performed using the world wide used Interactive Gravity and Magnetic Application System (IGMAS+) software. The software models geological bodies in 3D by polyhedrons on a series of parallel vertical cross-sections predefined in the model. The computed gravity or magnetic effect of each 3-D (polyhedral) body is added to the effect of the other ones, to give the anomaly value of the model structure for a given observation point which is compared with observed field. Iterative change of the model geometry structure optimizes the fit between the observed Bouguer and the calculated field [25] [26] [27] [28].

\section{Data}

\subsection{Gravity Data and Processing}

The ground gravity dataset were extracted from the Bouguer gravity anomaly map established by [29] and made available by IRD (Institut de Recherche pour le Développement, France). This dataset covers the region between longitudes latitudes $9^{\circ} 55^{\prime} \mathrm{N}$ to $13^{\circ} \mathrm{N}$ and between longitudes $14^{\circ} 10^{\prime} \mathrm{E}$ to $15^{\circ} 35^{\prime} \mathrm{E}$ and consists of approximately 1350 points. The measured points have a relatively even distribution throughout the study area (Figure 2), although the data are concentrated along major roads and tracks with a station spacing of $2-5 \mathrm{~km} \mathrm{[29].} \mathrm{All}$ the data were tied to the IGSN71 reference system, and a density of $2670 \mathrm{~kg} / \mathrm{m}^{3}$ was used for the Bouguer correction. The Bouguer map of the study area (Figure 2(a)) was generated with grid spacing of $5 \mathrm{~km}$.

The measured gravity field (Figure 2(a)) in North Cameroon usually shows the combined effect of a local associated with the superficial rocks and a regional caused by deeper structures in the earth's crust [6]. The large features generally show up as trends, which continue smoothly over a considerable distance. These trends are known as regional trends. Superimposed on the regional field, but frequently camouflaged by these, are the smaller, local disturbances which are secondary in size but primary in importance. The regional is usually separated from the total Bouguer field to obtain the residual anomalies. They may provide direct evidence of the existence of the reservoir structures in sedimentary basin or mineral ore bodies [30] [31]. Thus, to effectively use Bouguer gravity data to infer the properties of the anomaly due to sediment, the gravity anomalies of shallower sources most be enhanced. To this end, we calculate the gravity effect of the Moho (Figure 2(c)) and remove this effect from the total gravity field. By following this approach, we are sure to remove the effect of deeper sources from the gravity and therefore the upper crust signal is enhanced and useful for the purpose of our 3D model (Figure 2(d)). To calculate this gravity effect, we take advantage of the Moho map recently published by [32] (Figure 2(b)).

\subsection{Magnetic Data and Processing}

The aeromagnetic data used for this study were provided by GETECH and are 

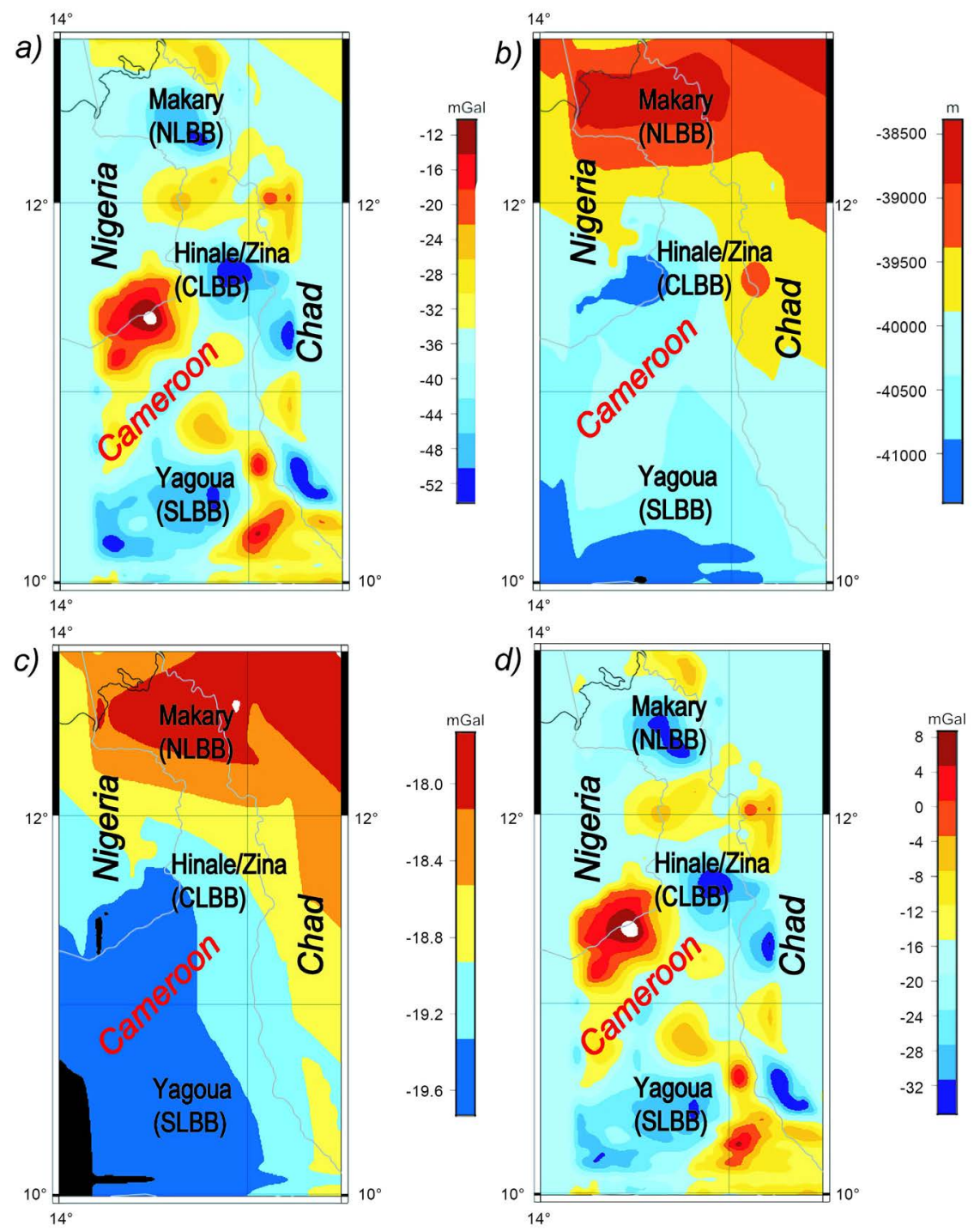

Figure 2. (a) Bouguer anomaly map; (b) Moho map extracted from [32]; (c) Gravity effect of Moho map; d) Isostatic residual anomaly map.

limited between latitudes $9^{\circ} 55^{\prime} \mathrm{N}$ to $13^{\circ} \mathrm{N}$ and between longitudes $14^{\circ} 10^{\prime} \mathrm{E}$ to $15^{\circ} 35^{\prime} \mathrm{E}$. They are part of the African Magnetic Mapping Project (AMMP) dataset compiled in 1992. The data have had the International Geomagnetic Reference Field (IGRF) removed and have been continued upward to produce a 0.01 $\times 0.01$ degree grid at $1000 \mathrm{~m}$ above the terrain [6]. The data were gridded at 5 $\mathrm{km}$ spacing. After performing the Reduction Pole (RTP) filtering operation on the gridded data (Figure 3(a)), continuation filtering was also performed on the RTP data with the use of oasis montaj computer program. Upward continuation is a way of enhancing large scale (usually deep) features in the survey area. It attenuates anomalies with respect to wavelength; the shorter the wavelength, the greater the attenuation [33].

Mathematically, the upward continuation method is based on the [30] expression: 

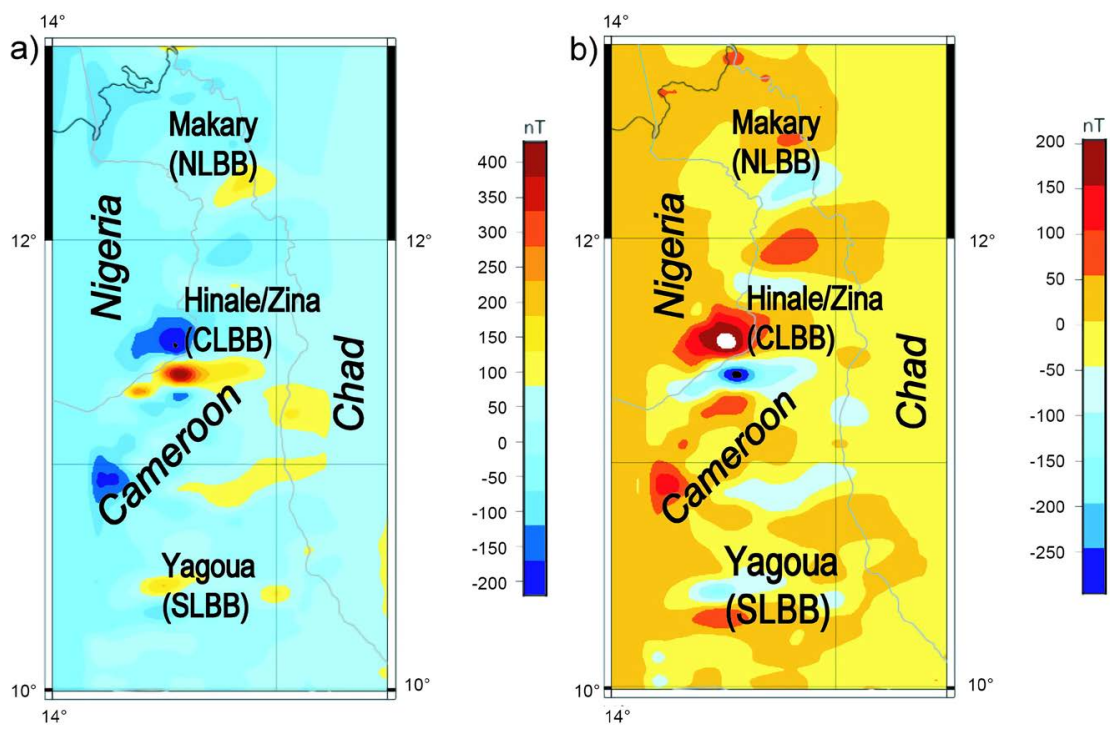

Figure 3. (a) Rtp magnetic map; (b) residual magnetic map.

$$
U\left(x, y, z_{0}-\Delta z\right)=\frac{\Delta z}{2 \pi} \int_{-\infty}^{+\infty} \int_{-\infty}^{+\infty} \frac{U\left(x^{l}, y^{l}, z_{0}\right)}{\left[\left(x-x^{l}\right)^{2}+\left(y-y^{l}\right)^{2}+\Delta z^{2}\right]^{\frac{3}{2}}} d x^{l} d y^{l}
$$

where $U\left(x, y, z_{0}-\Delta z\right)=$ to upward continuation parameters with respect to initial coordinate $x, y$ and $z_{0}-\Delta z$.

$Z=$ change in the magnetic field component

$U\left(x^{l}, y^{l}, z_{0}\right)=$ upward continuation parameter with respect to new Coordinate $x^{l}, y^{l}, z_{0}$

$d x^{l} d y^{l}=$ change in the new coordinate

$\left[\left(x-x^{l}\right)^{2}+\left(y-y^{l}\right)^{2}+\Delta z^{2}\right]^{\frac{3}{2}}=$ difference in the coordinates

Applying the Fourier convolution in the Equation (1) we have

$$
F\left[U_{u}\right]=F[U] F\left[\Psi_{u}\right]
$$

where

$$
\Psi_{u}(x, y, \Delta z)=\frac{\Delta z}{2\left(x^{2}+y^{2}+z^{2}\right)^{\frac{3}{2}}}
$$

Equation (1.b) is the analytical expression of $F\left[\Psi_{u}\right]$ where $F\left[U_{u}\right]$ is the Fourier transform of the upward continued field

$$
F\left[U_{u}\right]=e^{-z|k|}
$$

Equation (2) represents the Fourier transform of the initial coordinate when $\Delta z$ is greater than zero, $(\Delta z>0)$

The upward continuation filter was applied used at $12 \mathrm{~km}$ depth for onward interpretation of different sediment sequence structure of the LBB. The corresponding residual Magnetic anomaly map presented in Figure 3(b). 


\section{Modelling}

To model with IGMAS+, one necessarily needs to define an initial model structure, and density values of the bodies forming the model. To this end, we take advantage of a priori information from regional geology and tectonic previously published in the area.

The initial density structure is based on previous geophysical studies including the structure, the thickness and the composition of the basement and sediment layers. The study area was divided into 16 west to east oriented cross sections and long of about $150 \mathrm{~km}$, with average spacing of around $20 \mathrm{~km}$. From south to north direction $210 \mathrm{~km}$, the model is about $210 \mathrm{~km}$ wide. To avoid edge effects, the model structure was extended in all directions with more than $50 \mathrm{~km}$, and reaching $25 \mathrm{~km}$ in depth. The initial top basement boundary was defined following the prior basement geometry published by [8]. To account for the influence of sediment thickness across the study area, on the crustal structure, modelling of the basin subsurface configuration is difficult in Northern Cameroon due to the lack of constraining data like seismics, drilling or logging data. However, a six sub-layer model on the basis of seismic drillings results from adjacent basins to the LBB [7] [12] [13] [14] [15] [23] was chosen as a starting point for the 3D model, as it is proven that the LBB has undergone a similar tectonic and geological history with some of its neighbouring basins. To build an acceptable geological model, a density value for each modelled lithological unit is required. Rock densities were extracted from [7], whereas of magnetic susceptibility, stem from average values measured from rock samples worldwide [34] as no susceptibility measurements from rock samples, are publicly available. Rock densities and magnetic susceptibility values are shown in Table 1.

\section{Results}

In This section we present the results of our 3D forward model with the main

Table 1. Density and susceptibility values of different crustal units used for the 3D Model. Former densities are extracted from [7].

\begin{tabular}{|c|c|c|c|}
\hline \multirow{2}{*}{ FORMATION } & \multicolumn{2}{|c|}{ Density $\left(\mathrm{kg} / \mathrm{m}^{3}\right)$} & \multirow{2}{*}{$\begin{array}{c}\text { Final susceptibly } \\
\text { model }(S I)\end{array}$} \\
\hline & Former density mo & al density model & \\
\hline Keri Keri - Chad formation & 2100 and 2300 & $2000-2150$ & 0 \\
\hline Gombe formation & & $2250-2300$ & \\
\hline Fika (+volcanic bodies) & $2350-(2800)$ & $2330-(2850)$ & $0-(0.02)$ \\
\hline $\begin{array}{l}\text { Gongila formation } \\
\text { (+volcanic bodies) }\end{array}$ & $2350-(2800)$ & $2400-(2850)$ & $0-(0.04)$ \\
\hline $\begin{array}{l}\text { Bima formation } \\
\text { (+volcanic bodies) }\end{array}$ & $2550-(2700)$ & $2490-(2900)$ & $0-(0.035)$ \\
\hline $\begin{array}{c}\text { Pre-Bima formation } \\
\text { (+volcanic bodies) }\end{array}$ & $2550-(2700)$ & $2580-(2900)$ & $0-(0.035)$ \\
\hline Basement & 2700 & 2700 & $0.001-0.002$ \\
\hline
\end{tabular}


focus of different sediments facies in the LBB. The model we present here is one of the possible solutions trying to match as much potential field data.

The misfit between the observed (Figure 4(a) and Figure 4(b)) and the computed anomaly (Figure 4(c) and Figure 4(d)) are shown in Figure 4(e) and Figure 4(f). The maximum and minimum misfit values are $\pm 13 \mathrm{mGal}$ for the
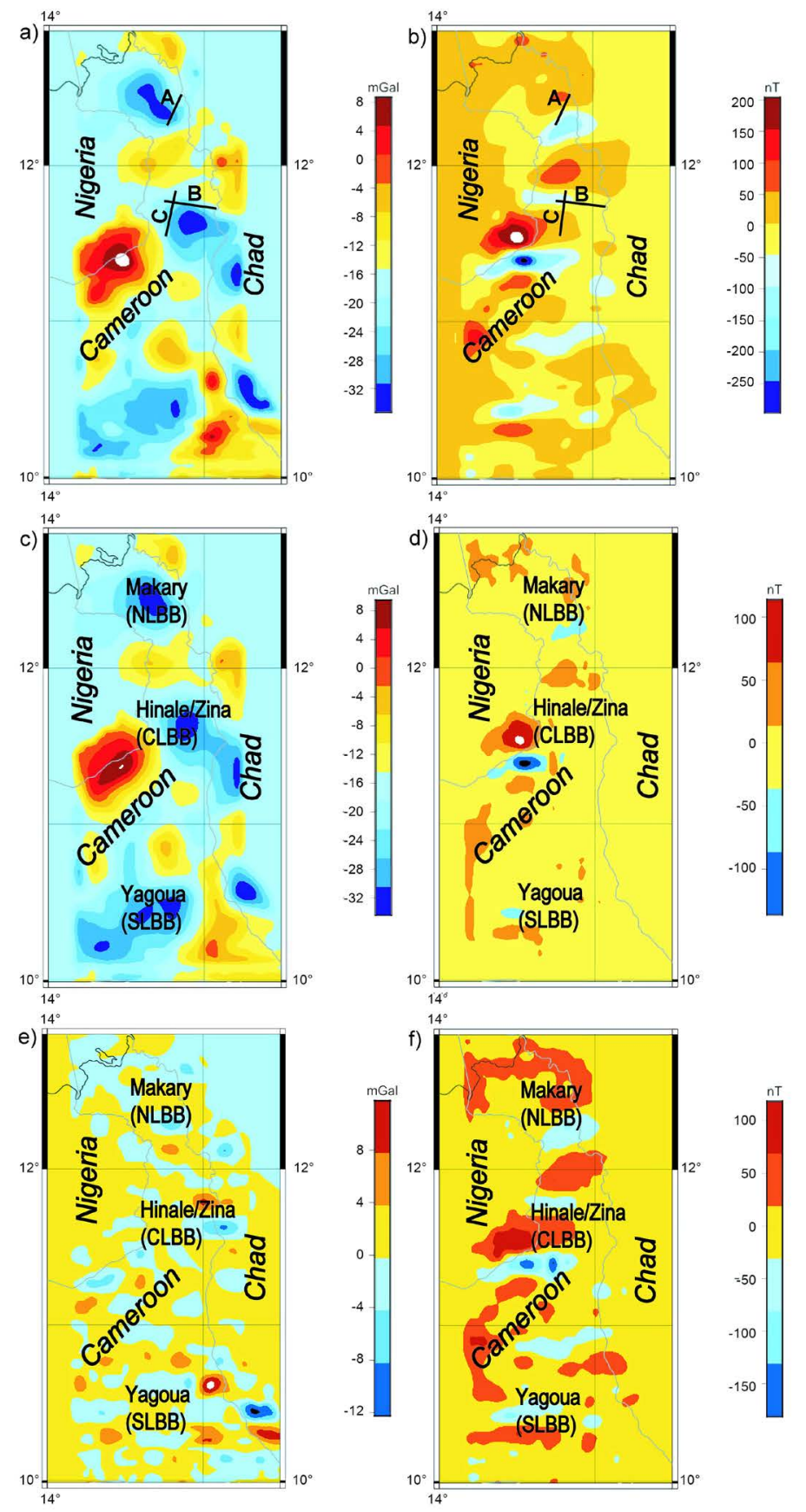

Figure 4. (a) Observed gravity map; (b) Observed magnetic map; (c) Computed gravity map; (d) Computed magnetic map; (e) The misfit between the observed and computed Bouguer anomaly of the study area; (f) The misfit between the observed and computed magnetic anomaly of the study area; Black thick lines represent the location of Cross sections $\mathrm{A}, \mathrm{B}$ and $\mathrm{C}$ extracted from the 3D model. 
Bouguer anomalies, and between $100 \mathrm{nT}$ and -181 nT for the magnetic anomalies respectively.

Three selected profiles were used to illustrate the result of the forward gravity/magnetic model. They were selected so that they overlap the seismic sections previously published by [7]. One has to acknowledge that even though the resolution of these previous seismic sections is relatively low; they provide first order information on different major structures encountered in the basin. The cross sections display density structure in the lower panel and computed as well as observed gravity and magnetic values are presented in the upper panel.

Cross section A (Figure 5) is oriented SW-NE and crosses the southeast of Makary sub-basin, south of Lake Chad. Along this profile, the Bouguer anomalies vary from -13 to $-30 \mathrm{mGal}$ and the magnetic anomalies vary from -185 to $150 \mathrm{nT}$. The minimum gravity anomaly is located around the center of the profile, and according to our model, this area shows by far the most important sedimentary thickness, ca. $3500 \mathrm{~m}$. We also observe that the basement is strongly ridged and faulted. The different sediments sequences previously mentioned are all visible in this section with their variable thicknesses. Some of them are faulted

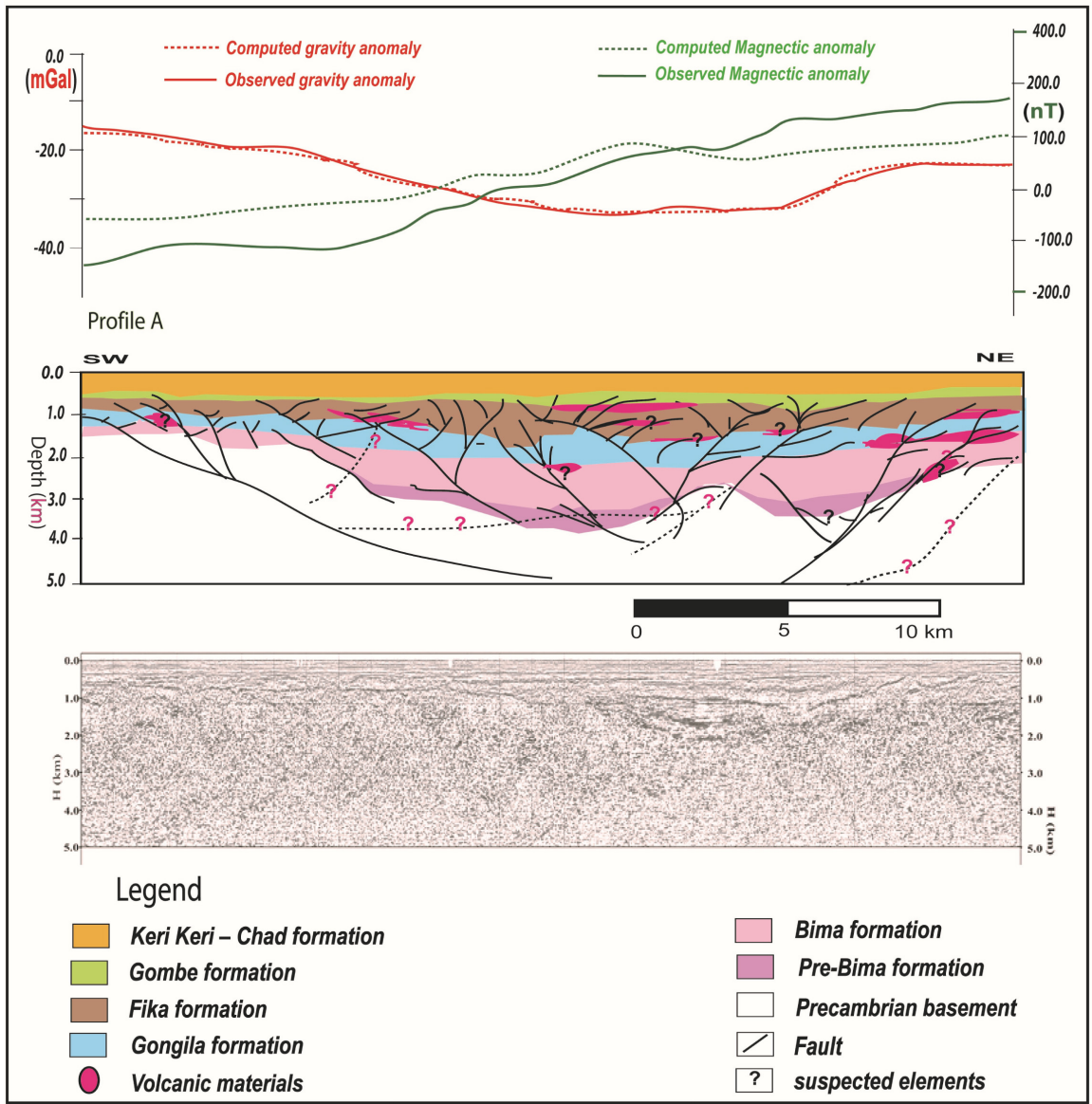

Figure 5. Cross section A (NLBB). Bottom: uninterpreted depth migrated seismic section. Middle: structural interpretation of different formation units and volcanic bodies. Top: modeled gravity and magnetic fields. 
and intruded by volcanic bodies with depth ranging from 800 to $1500 \mathrm{~m}$. Our model seems to mimic the seismic section, even though there are some suspected faults and intrusive bodies that are not clearly visible in the seismic section.

Cross section B (Figure 6) is runs NW-SE and passes through the north of Hinale sub-basin. Here, the Bouguer anomaly varies from -11 to $-28 \mathrm{mGal}$ and the magnetic anomalies vary from 2 to $-100 \mathrm{nT}$. The maximum sediment thickness, ca.4000 $\mathrm{m}$ is around the center of the profile and coincides with the minimum Bouguer anomaly. Like in the previous section, the Pre-Bima sequence shows limited extent. We note that section A and section B almost show similar structure, at the difference that the distribution of intrusive is unequal. In cross section $\mathrm{B}$, the volcanic activity seems intense and the volcanic bodies are deeper compared to section A (between 1000 to $4000 \mathrm{~m}$ ).

Cross section C (Figure 7) which runs west of the Hinale sub-basin, south of Chad Lake is oriented SW-NE. The Bouguer field variation along this profile displays irregular shape. One can observe that the basement structure follows this variation of the Bouguer anomaly. The Bouguer low corresponds to important sediment pill, around $4000 \mathrm{~m}$ thick, whereas the Bouguer high coincides

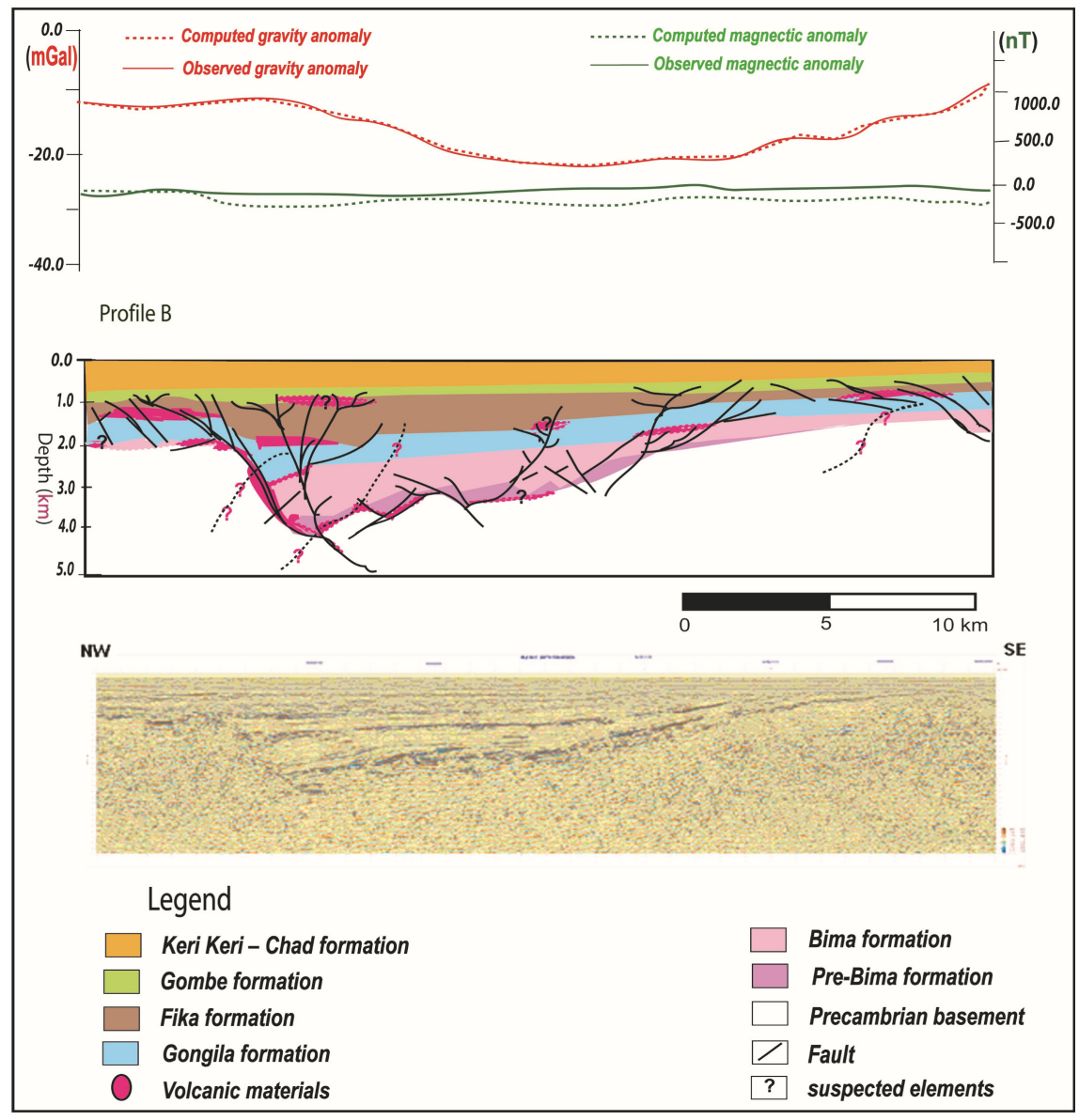

Figure 6. Cross section B (CLBB). Bottom: uninterpreted depth seismic section. Middle: structural interpretation of different formation units and volcanic bodies. Top: modelled gravity and magnetic fields. 


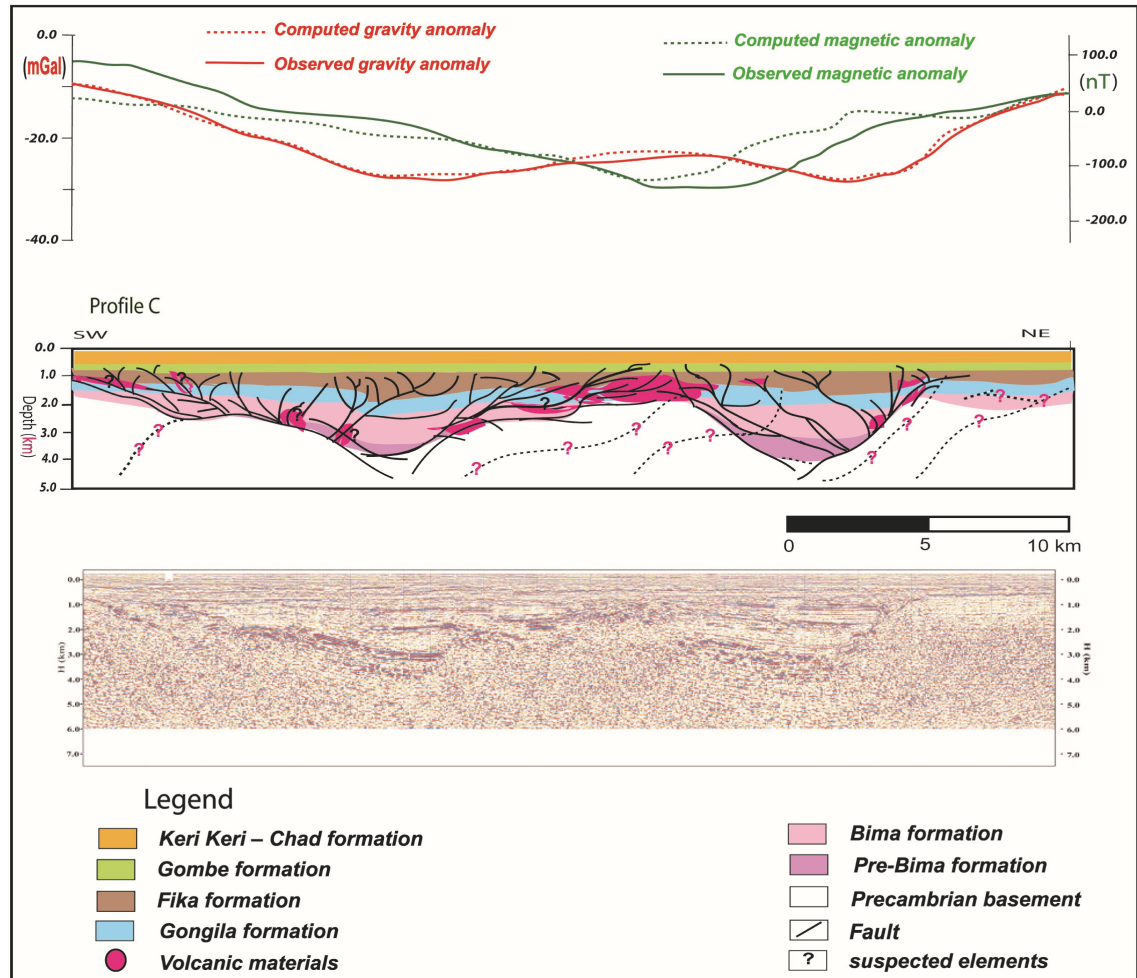

Figure 7. Cross section C (CLBB). Bottom: depth seismic section. Middle: structural interpretation of different formation units and volcanic bodies. Top: modelled gravity and magnetic fields.

with the basement uplift. From our Model, the Hinale subbasin seems to be represented by two half grabens. This section displays important volcanic activity that mainly occurs in the flanks of basement horsts separating the two half grabens. Numerous major thrust faults are found within sedimentary sequences from the Fika Formation down to the Pre Bima formations.

Figure 8 represents the regional geometrical trend of different sediment sequences of the LBB extracted from the 3D model.

\section{Pre-Bima formation}

This sequence is defined as the oldest and the basal lithological sedimentary formation (Figure 8(f)). The Pre-bima formation is the deepest lithostratigraphic among the strata and directly overlies the basement in the LBB. The model indicates that this formation is weakly widespread in the study area and mainly concentrate on CLBB and the NLBB where it shows major thickness, more than $700 \mathrm{~m}$ compared to the Yagoua sub basin where the thickness is less than $400 \mathrm{~m}$. It can be seen that in the rest of the study area, the mean thickness for this layer is less than $20 \mathrm{~m}$; this may indicate great influence of structural highs on this unit.

\section{Bima formation}

Overlying pre-bima formation is the Upper Albian Bima formation. This formation is widespread, and strikes the entire study area. Our model shows that the Bima formation is more than $1700 \mathrm{~m}, 1400 \mathrm{~m}$ and $1100 \mathrm{~m}$ thick in the 


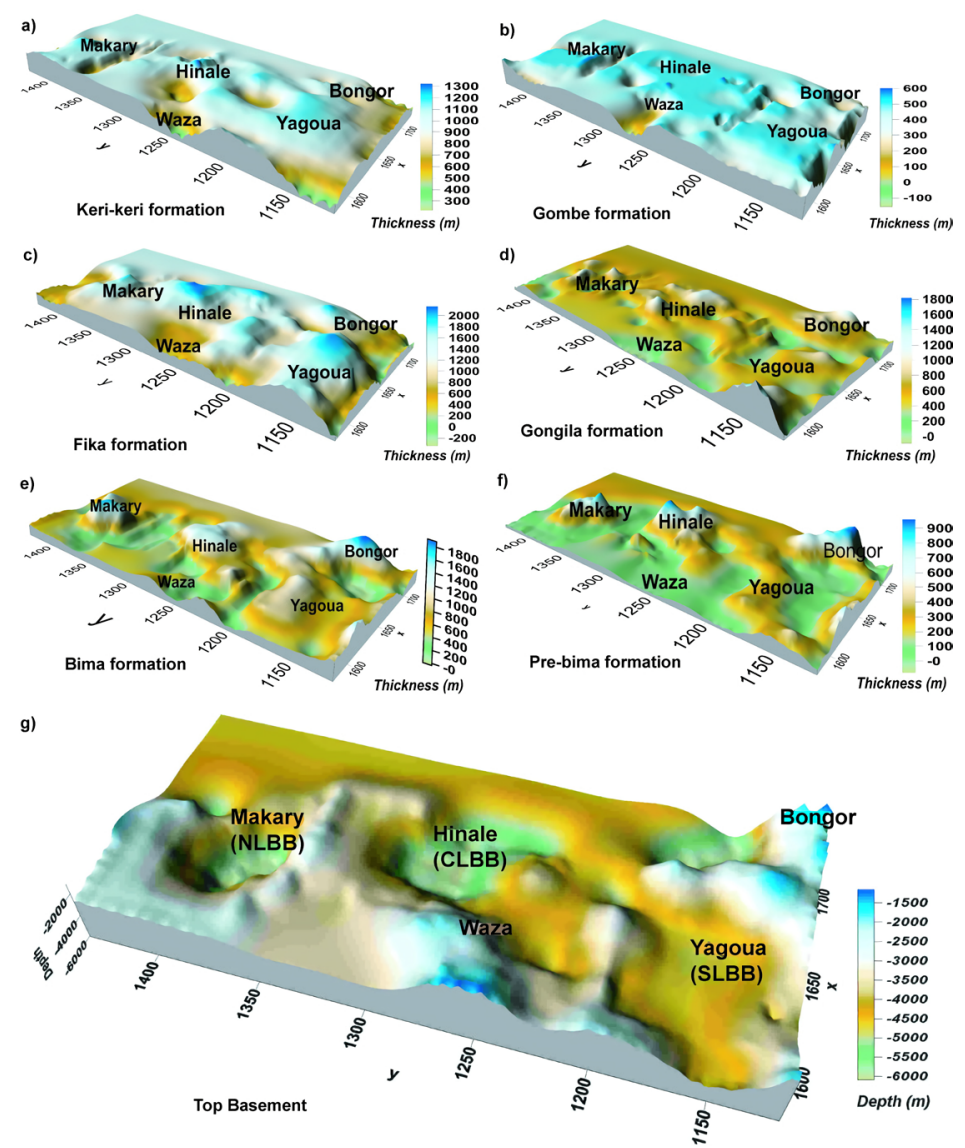

Figure 8. Distribution of Sediment thickness (Stratigraphy sequences) and depth in the LBB. (a) The Keri Keri formation; (b) The Gombe formation; (c) The Fika Formation; (d) The Gongila formation; (e) The Bima formation; (f) The Pre-bima formation; (g) Top basement map.

northern, central and southern logone birni basin respectively (Figure 8(e)). This layer is thicker compared to the Pre-bima formation.

\section{Gongila formation}

Similar to Bima formation, Gongila formation is also presents across all the depressions in the study area (Figure 8(d)). Our model shows that this formation thickens to the north of Makary and the east of Hinale where the thickness reaches $1100 \mathrm{~m}$, whereas it thins with less than $900 \mathrm{~m}$ in the south (SLBB).

\section{Fika formation}

The Gongila formation is overlain the Turonian-Senonian Fika Formation which is also extensive in the LBB (Figure $8(\mathrm{c})$ ). According to our model, the Fika formation is almost equivalently thick along the three most important depocenters in the LBB (CLBB, NLBB, and SLBB), with around $1900 \mathrm{~m}$ of sediments. In the rest of the study area, this layer is thin with less than $600 \mathrm{~m}$.

\section{Gombe formation}

Also expanded all over the LBB, the Gombe formation seems relatively thin compared to the Fika formation. Its thickness is not more than $500 \mathrm{~m}$ in the three main depocenters (Figure 8(b)), with the mean thickness of around 300 
m.

\section{Keri-keri}

The Keri-keri formation (Figure 8(a)) is the uppermost layer in the LBB. According to our model, there is no important thickness variation of this layer throughout the area of study and reaches a maximum thickness of $500 \mathrm{~m}$.

\section{Discussion}

The 3D geophysical model of the LBB is discussed and we focus our discussion on the architecture of different sediment strata, thickness distribution, localization of volcanic rocks and possible hydrocarbon implications. The 3D forward modeling was used and constrained by seismic sections published by [7] in order to exhibit sources of potential field anomalies within the LBB.

\subsection{Top Basement}

The top basement map (Figure $8(\mathrm{~g})$ ) obtained from the 3D forward modeling shows its maximum depth of about $6000 \mathrm{~m}$ in the Makary sub-basin (NLBB), and its minimum in the Yagoua sub-basin south (SLBB) with the depth around $4400 \mathrm{~m}$. This result agrees with [7] but contradicts [8] who presented a deeper basement compared to our result (Table 2). But similar to [8] and [9], our basement displays important topography variations throughout the study area (Figure 8(g)). From this observation, these authors concluded that the basement was strongly ridged and faulted. However, our model exhibits limited basement-involved fault in the central and south of the LBB, contrary to the northern part which seems highly faulted, with some of the faults showing compressional imprints [7], probably indicating inversion of this part of the basin during the Lower Cretaceous times. This result is in good agreement with [7], who previously mentioned compressional offset in this part of the LBB.

\subsection{Stratigraphic Sequences and Hydrocarbons}

Our model shows that throughout LBB, the Pre-Bima layer lies directly on the basement, with a maximum thickness of about $900 \mathrm{~m}$ (Figure 8(f)). This layer has also been identified in the nearest basin, the Bornu basin where it shows important thickness, ca. $3000 \mathrm{~m}$ [15]. There are limited evidences helping to identify the origin of the thicknesses gap between this two basins, as they are supposed to undergone the similar tectonic history. However, we may speculate

Table 2. Comparison of sediment thickness obtained from various studies. Sediment thickness is in meter (m). CLBB = Central Logone Birni Basin, SLBB: Southern Logone Birni basin.

\begin{tabular}{ccccc}
\hline Basins & {$[8]$} & {$[5]$} & {$[9]$} & {$[35]$} \\
\hline Makary (NLBB) & 5500 & & & 6000 \\
Hinale/Zina (CLBB) & 5800 & & 5830 & 5850 \\
Yagoua (SLBB) & 4300 & 3100 & 4200 & 4400 \\
\hline
\end{tabular}


that the post rift thermo-tectonic subsidence in the region [1] [19] [20] may have had minor influence in the LBB compared to the Bornu basin.

In general, the Bima formation (Figure 8(e)) overlies the Pre-bima formation, even though it is directly in contact with the basement in some places where the Pre-Bima does not exist. It thickness varies from $1100 \mathrm{~m}$ in Yagoua subbasin (SLBB) up to $1700 \mathrm{~m}$ in Makary subbasin (NLBB) where the maximum thickness is found. [12] [14] [16] found similar results in the Bornu Basin. Our model (Figures 5-7) shows that the pre-bima and bima formations are strongly folded and faulted within the study area. These results are supported by [15] who have previously shown that folding in common feature sedimentary layers in southern Chad basins and that this originate from the reopening of pre-existing rift graben following the oblique extension and further subsidence and the compaction of sediments.

According to our model, the thickness of the Gongila formation is irregularly distributed in the $\mathrm{LBB}$ and is reaches his maximum of about $1100 \mathrm{~m}$ around the Makary subbasin and east of the CLBB (Figure 8(d)). [12] [15] reported similar thickness for this layer in the Bornu basin. Our model also shows that the Fika formation (Figure 8(c)) is the thickest layer in the LBB and reaches $2000 \mathrm{~m}$ in the CLBB. Similar results were found in exploration wells east of the Bornu basin close to the CLBB [12] [14].

The two uppermost layers namely the Gombe (Figure 8(b)) and the Keri-keri (Figure 8(a)) formations do not present important variations compared to the other layers. They can be found all over the study area where their thickness does not exceed $250 \mathrm{~m}$ for the Gombe and $500 \mathrm{~m}$ for the Keri-keri layer. Our result is in good agreement with [7] [14] [17] who find similar results in the southern Chad basins.

Early Cretaceous to Recent Sediment rocks that fills the LBB attains the thickness of approximately $6000 \mathrm{~m}$. [36] has shown that $35 \%$ of rifted basins contain giant oil fields (e.g., the intra-oceanic rift system of the North Sea and the epicontinental Sirte embayment in Libya) as it is the case of LBB. Therefore the discoveries of oil in its nearby Chadian and Nigeria basins coupled with the important sediment thickness and the ages of rocks probably indicated that the LBB may have significant hydrocarbon prospect.

Previous investigations indicate the discoveries of petroleum and gaz fields to the Nigeria Bornu basin and that the source rocks are Bima and Fika formations [13] [37] [38]. The Gongila and Gombe are also suitable reservoirs [39]. From the above description, each part of the LBB is potentially prospective. However the deepest part of the basin, the Makary subbasin may hold the best condition for hydrocarbon generation and accumulation but the limited presence of faults and intrusive bodies decreases the possibility of thermal degeneration and potential of structural and stratigraphic traps. In contrast, our model shows that the CLBB may fulfill the conditions for hydrocarbon generation and maturity. The folded area dominated from top to bottom by intrusive rocks, even though the rapid sedimentation may affect the geothermal gradient in fold areas, the 
great sediment thickness may ensure the great rocks maturation as it is the case of Niger delta [15] and Bornu basin [40].

\section{Conclusion}

The interpretation of gravity and magnetic data together with the modeling software package IGMAS+ as enabled the establishment of a 3-D model of the LBB, was constrained by available seismic profiles. The thickness and the distribution of the geometry of each formation (Kerri-kerri, Gombe, Fika, Gongila and Bima) and the whole sediment package have been figured out. The Model shows that each part of the LBB is potentially prospective for petroleum exploration, like the Makary subbasin which is the deepest part of the LBB, but the limited presence of faults and intrusive bodies along this layer may not favor the presence of traps or thermal rock maturity. In return, the structural style of the CLBB, which is almost similar with the Bornu in Nigeria, is an indication of good prospects for possible hydrocarbon plays in this area. However, at the present level of knowledge, it is hard to introduce further details on the model structure, as sufficient further information is not available. It is therefore vital that additional new investigations are needed, including wells drillings, 3D seismic technique or organic geochemistry in order to better figure of the subsurface geology of the LBB. This would help to draw final conclusions on the petroleum prospects of this basin.

\section{Acknowledgements}

We are very grateful to H.-J. Götze and S. Schmidt from the Christian-Albrechts-University of Kiel, Germany, for freely providing IGMAS+ software.

\section{Conflicts of Interest}

The authors declare no conflicts of interest regarding the publication of this paper.

\section{References}

[1] Genik, G.J. (1992) Regional Framework, Structural and Petroleum Aspects of Rift Basins in Niger, Chad and the Central African Republic (C.A.R.). Tectonophysics, 213, 169-185. https://doi.org/10.1016/0040-1951(92)90257-7

[2] Burke, K. (1976) The Chad Basin: An Active Intra-Continental Basin. Developments in Geotectonics, 12, 197-206. https://doi.org/10.1016/B978-0-444-41549-3.50018-9

[3] Browne, S.E. and Fairhead, J.D. (1983) Gravity Study of the Central African Rift System: A Model of Continental Disruption 1. The Ngaoundere and Abu Gabra Rifts. Tectonophysics, 94, 187-203. https://doi.org/10.1016/0040-1951(83)90016-1

[4] Fairhead, J.D. and Okereke, C.S. (1987) A Regional Gravity Study of the West African Rift System in Nigeria and Cameroon and Its Tectonic Interpretation. Tectonophysics, 143, 141-159. https://doi.org/10.1016/0040-1951(87)90084-9 
[5] Njandjock Nouck, P., Manguelle-Dicoum, E., Ndougsa-Mbarga, T. and Charles Tabod, T. (2006) Spectral Analysis and Gravity Modelling in the Yagoua, Cameroon, Sedimentary Basin. Geofísica Internacional, 45, 209-215.

[6] Eyike, A., Werner, S.C., Ebbing, J. and Dicoum, E.M. (2010) On the Use of Global Potential Field Models for Regional Interpretation of the West and Central African Rift System. Tectonophysics, 492, 25-39. https://doi.org/10.1016/j.tecto.2010.04.026

[7] Loule, J.P. and Pospisil, L. (2013) Geophysical Evidence of Cretaceous Volcanics in LogoneBirni Basin (Northern Cameroon), Central Africa, and Consequences for the West and Central African Rift System. Tectonophysics, 583, 88-100. https://doi.org/10.1016/j.tecto.2012.10.021

[8] Eyike, A. and Ebbing, J. (2015) Lithospheric Structure of the West and Central African Rift System from Regional Three-Dimensional Gravity Modelling. South African Journal of Geology, 118, 285-298. https://doi.org/10.2113/gssajg.118.3.285

[9] Epuh, E.E. and Joshua, E.O. (2017) Basement Depth and Sedimentary Velocity Structure in Gongola Basin. Journal of Geology \& Geophysics, 6, 285. https://doi.org/10.4172/2381-8719.1000285

[10] Elad, M., Eyike, A., Basseka, C.A. and Som Mbang, C.M. (2017) Top Basement Structure of the Northernmost Cameroon and Southern Chad Sedimentary Basin from Gravity Data. Sciences, Technologies et Developpement, 19, 49-62.

[11] Epuh, E.E. and Joshua, E.O. (2017) Basement Depth and Sedimentary Velocity Structure in Gongola Basin. Journal of Geology \& Geophysics, 6, 285. https://doi.org/10.4172/2381-8719.1000285

[12] Aderoju, A.B., Ojo, S.B., Adepelumi, A.A. and Edino, F. (2016) A Reassessment of Hydrocarbon Prospectivity of the Chad Basin, Nigeria, Using Magnetic Hydrocarbon Indicators from Highresolution Aeromagnetic Imaging. Ife Journal of Science, 18, 503-520.

[13] Olabode, S.O., Adekoya, J.A. and Ola, P.S. (2015) Distribution of Sedimentary Formations in the Bornu Basin, Nigeria. Petroleum Exploration and Development, 42, 674-682. https://doi.org/10.1016/S1876-3804(15)30062-8

[14] Sunday, O.P., Adekoya, A. J. and Ojo, O.S. (2018) Source Rock Evaluation of the Southwest Portion of the Bornu Basin, Nigeria. IOSR Journal of Applied Geology and Geophysics, 6, 27-31.

[15] Mohammed, Y.B. (2010) Geochemical Assessment of Cretaceous Sediments in the Nigerian Sector of the Chad Basin from Kadaru-1 and Herwa-1 Exploratory Wells for Possible Petroleum Generation. Journal of Environmental Sciences and Resource Management, 2, 23-36

[16] Hamza, H., Obaje, N.G. and Obiosio, E.O. (2002) Foraminiferal Assemblage and Palaoenvironment of the Fika Shale, Bornu Basin, Northeastern Nigeria. Journal of Mining and Geology, 38, 49-56. https://doi.org/10.4314/jmg.v38i1.18774

[17] Milesi, J.P., Toteu, S.F., Deschamps, Y., Feybesse, J.L., Lerouge, C., Cocherie, A., Nicol, N., et al. (2006) An Overview of the Geology and Major Ore Deposits of Central Africa: Explanatory Note for the 1: 4,000,000 Map "Geology and Major Ore Deposits of Central Africa”. Journal of African Earth Sciences, 44, 571-595. https://doi.org/10.1016/j.jafrearsci.2005.10.016

[18] Schlüter, T. (2006) Geological Atlas of Africa. Springer-Verlag, Berlin, Heidelberg, Germany.

[19] Guiraud, R. and Maurin, J.C. (1992) Early Cretaceous Rifts of Western and Central 
Africa: An Overview. Tectonophysics, 213, 153-168. https://doi.org/10.1016/0040-1951(92)90256-6

[20] Guiraud, M. (1993) Late Jurassic Rifting-Early Cretaceous Rifting and Late Cretaceous Transpressional Inversion in the Upper Benue Basin (NE Nigeria). Bulletin Des Centres de Recherches Exploration-Production Elf Aquitaine, 17, 371-383.

[21] Mothersill, J.S. (1975) Lake Chad: Geochemistry and Sedimentary Aspects of a Shallow Polymictic Lake. SEPM Journal of Sedimentary Research, 45, 295-309. https://doi.org/10.1306/212F6D48-2B24-11D7-8648000102C1865D

[22] Petters, S.W. and Ekweozor, C.M. (1982) Petroleum Geology of Benue Trough and Southeastern Chad Basin, Nigeria: GEOLOGIC NOTES. AAPG Bulletin, 66, 1141-1149. https://doi.org/10.1306/03B5A65B-16D1-11D7-8645000102C1865D

[23] Manga, C.S., Loule, J.P. and Koum, J.J. (2001) Tectonostratigraphic Evolution and Prospectivity of the Logone Birni Basin, North Cameroon-Central Africa. American Association of Petroleum Geologists Bulletin, 85, 1-6.

[24] Guiraud, R., Binks, R.M., Fairhead, J.D. and Wilson, M. (1992) Chronology and Geodynamic Setting of Cretaceous-Cenozoic Rifting in West and Central Africa. Tectonophysics, 213, 227-234. https://doi.org/10.1016/0040-1951(92)90260-D

[25] Götze, H.J. (1984) Über den Einsatz interaktiver Computergraphik im Rahmen 3-dimensionaler Interpretationstechniken in Gravimetrie und Magnetik. Doctoral Dissertation, Technische Universität Clausthal, Clausthal-Zellerfeld, Germany.

[26] Götze, H.J. and Lahmeyer, B. (1988) Application of Three-Dimensional Interactive Modeling in Gravity and Magnetics. Geophysics, 53, 1096-1108. https://doi.org/10.1190/1.1442546

[27] Schmidt, S. and Götze, H.J. (1998) Interactive Visualization and Modification of 3D-Models Using GIS-Functions. Physics and Chemistry of the Earth, 23, 289-295. https://doi.org/10.1016/S0079-1946(98)00027-5

[28] Schmidt, S., Plonka, C., Gotze, H.J. and Lahmeyer, B. (2011) Hybrid Modelling of Gravity, Gravity Gradients and Magnetic Fields. Geophysical Prospecting, 59, 1046-1051. https://doi.org/10.1111/j.1365-2478.2011.00999.x

[29] Poudjom-Djomani, Y.H., Boukeke, D.B., Legeley-Padovani, A., Nnange, J.M., Albouy, Y. and Fairhead, J.D. (1996) Levés gravimétriques de reconnaissance: Cameroun=Gravity Map of Cameroon. ORSTOM, Paris.

[30] Blakely, R.J. (1996) Potential Theory in Gravity and Magnetic Applications. Cambridge University Press, Cambridge, England. https://doi.org/10.1017/CBO9780511549816

[31] Ofoha, C.C. (2015) M.Sc. Thesis, University of Port Harcourt, Choba, Nigeria. (Unpublished)

[32] Eyike, A., Nyam, F.E.A. and Basseka, C.A. (2018) Topography of the Moho Undulation in Cameroon from Gravity Data: Preliminary Insights into the Origin, the Age and the Structure of the Crust and the Upper Mantle across Cameroon and Adjacent Areas. Earth \& Environmental Sciences, 8, 65-85. https://doi.org/10.4236/ojg.2018.81005

[33] Mekonnen, T.K. (2004) Interpretation and Geodatabase of Dykes Using Aeromagnetic Data of Zimbabwe and Mozambique. M.Sc. Thesis, ITC, Delft, 80 p.

[34] Telford, W.M., Telford, W.M., Geldart, L.P. and Sheriff, R.E. (1990) Applied Geophysics, Cambridge University Press, Cambridge, England.

https://doi.org/10.1017/CBO9781139167932 
[35] Nguimbous-Kouoh, J.J., Ndougsa-Mbarga, T., Njandjock-Nouck, P., Eyike, A., Campos-Enriquez, J.O. and Manguelle-Dicoum, E. (2010) The Structure of the Goulfey-Tourba Sedimentary Basin (Chad-Cameroon): A Gravity Study. Geofísicainternacional, 49, 181-193.

[36] Klemme, H.D. (1980) Petroleum Basins-Classifications and Characteristics. Journal of Petroleum Geology, 3, 187-207. https://doi.org/10.1111/j.1747-5457.1980.tb00982.x

[37] Mohammed, A.Y., Pearson, M.J., Ashcroft, W.A., Illiffe, J.E. and Whiteman, A.J. (1999) Modeling Petroleum Generation in the Southern Muglad Rift Basin, Sudan. AAPG Bulletin, 83, 1983-1964. https://doi.org/10.1306/E4FD464D-1732-11D7-8645000102C1865D

[38] Obaje, N.G., Wehner, H., Hamza, H. and Scheeder, G. (2004) New Geochemical Data from the Nigerian Sector of the Chad Basin: Implications on Hydrocarbon Prospectivity. Journal of African Earth Sciences, 38, 477-487. https://doi.org/10.1016/j.jafrearsci.2004.03.003

[39] Moumouni, A., Obaje, N.G., Nzegbuna, A.I. and Chaanda, M.S. (2007) Bulk Geochemical Parameters and Biomarker Characteristics of Organic Matter in Two Wells (Gaibu-1 and Kasade-1) from the Bornu Basin: Implications on the Hydrocarbon Potential. Journal of Petroleum Science and Engineering, 58, 275-282. https://doi.org/10.1016/j.petrol.2007.01.004

[40] Adegoke, A.K., Yandoka, B.M.S., Abdullah, W.H. and Akaegbobi, I.M. (2015) Molecular Geochemical Evaluation of Late Cretaceous Sediments from Chad (Bornu) Basin, NE Nigeria: Implications for Paleodepositional Conditions, Source Input and Thermal Maturation. Arabian Journal of Geosciences, 8, 1591-1609.

https://doi.org/10.1007/s12517-014-1341-y 